\title{
UVA + B treatment affects antioxidant system and phytochemicals of parsley plant under different concentrations of $\mathrm{Zn}$
}

\author{
Masoumeh ABEDINI ${ }^{1}$, Behrokh DAIE-HASSANI ${ }^{1}$, Shirwan MALAEI $^{2}$
}

Received September 14, 2016; accepted February 28, 2017.

Delo je prispelo 14. septembra 2016, sprejeto 28. februarja 2017.

\begin{abstract}
Decline in ozone layer that followed by enhanced solar UV radiation is a limiting factor for some plants. In this study the effect of UVA+UVB radiation on parsley plant was studied hydroponically at different concentrations of $\mathrm{Zn} \mathrm{(1.5} \mathrm{and}$ $6.5 \mu \mathrm{m})$. UV radiation at both concentrations of $\mathrm{Zn}$, slightly decreased the plant growth and significantly increased the carotenoids, flavonoids, total phenols and $\mathrm{H}_{2} \mathrm{O}_{2}$ contents, but had no effect on chlorophylls content. At concentration of $1.5 \mu \mathrm{m}$ of $\mathrm{Zn}, \mathrm{UV}$ radiation caused significant increases in the MDA and anthocyanin contents and the activities of POD and CAT enzymes, but decreased the soluble sugars and protein contents. At concentration of $6.5 \mu \mathrm{m}$ of $\mathrm{Zn}$, UV radiation caused significant increases in the CAT activity, but had no significant effect on other parameters. Results suggest that parsley plant tolerates UVA+UVB radiation particularly at concentration of $6.5 \mu$ mof $\mathrm{Zn}$.
\end{abstract}

Key words: antioxidant enzymes; parsley; photochemicals; $\mathrm{UVA}+\mathrm{B} ; \mathrm{Zn}$
IZVLEČEK

\author{
OBRAVNAVANJE Z UVA + UVB VPLIVA NA \\ ANTIOKSIDACIJSKI SISTEM IN KEMIZEM \\ PETRŠILJA PRI RAZLIČNIH KONCETRACIJAH Zn
}

Tanjšanje ozonske plasti, ki mu sledi povečano UV sončevo sevanje sta omejujoči dejavnik za nekatere rastline. V tej raziskavi je bil preučevan učinek UVA+UVB sevanja na hidroponsko gojen peteršilj pri različnih koncentracijah $\mathrm{Zn}$ (1.5 in $6.5 \mu \mathrm{m})$. UV sevanje je pri obeh koncentracijah cinka rahlo zmanjšalo rast in značilno povečalo vsebnost karotenoidov, flavonoidov, celokupnih fenolov in $\mathrm{H}_{2} \mathrm{O}_{2}$, a brez učinka na vsebnost klorofilov. Pri koncentraciji $1.5 \mu \mathrm{m} \mathrm{Zn}$, je UV sevanje povzročilo značilno povečanje vsebnosti MDA in antocianinov, povečalo je aktivnosti encimov POD in CAT, a zmanšalo vsebnost topnih sladkorjev in beljakov. Pri koncentaraciji $6.5 \mu \mathrm{m}$ Zn je UV sevanje povzročilo značilno povečanje $\mathrm{v}$ aktivnosti CAT, a ni imelo značilnega učinka na ostale parametre. Rezultati nakazujejo, da peteršilj dobro prenaša UVA+UVB sevanje, še posebej pri koncentraciji $6.5 \mu \mathrm{m} \mathrm{Zn}$.

Ključne besede: antioksidacijski encimi; peteršilj; kemizem rastlin; UVA + B; Zn

\section{INTRODUCTION}

Interruption of ozone layer as an outcome of human activities has resulted to enhanced intensity of UV radiation on the Earth surface. Plants have obligate requirement for sun light are more susceptible to this radiance. UV radiation increases the production of reactive oxygen species (ROS) that are extremely cytotoxic (Mahdavian et al., 2008; Czégény et al., 2016). The antioxidant system is one of the most important mechanisms responsible for detoxifying the free radicals. Non-enzymatic antioxidant system includes biochemicals such as carotenoids, flavonoids, ascorbic acid and glutathione. Flavonoids commonly absorb the light in the region of $280-320 \mathrm{~nm}$ and thus are capable to protect the plant from damage (Eichholz et al., 2011; Reshmi and Rajalakshmi, 2012). Carotenoids also have antioxidant properties and act as an internal filter against UV radiation (Nasibi and Kalantari, 2005). Enzymatic antioxidants such as catalase, peroxidase and superoxide dismutase can moderate the UV-induced injuries by protecting the photosynthetic pathway and cellular components (Wei et al., 2013). A wide range of morphological,

1 Assistant Professor of Payame Noor University, Faculty of Basic Sciences, Department of Biology, Iran, corresponding author: ms_abedini@pnu.ac.ir

2 M.Sc. student of Payame Noor University, Faculty of Basic Sciences, Department of Biology, Iran 
physiological and biochemical responses of plants have been reported to elevate the UV resistance. Some plants are more tolerant to UV radiation than others because they activate a variety of mechanisms against stress (Fedina et al., 2010; Wei et al., 2013).

Zinc is an essential micronutrient and involves in the various metabolic pathways in plants (Alloway, 2008).
The positive role of $\mathrm{Zn}$ in different environmental stresses such as salinity, drought and high irradiance was reported by several authors (Hassan et al., 2005; Weisany et al., 2012; Michael and Krishnaswamy, 2014). In this study the effect of UVA + B treatment on parsley plant antioxidant system and phytochemicals was investigated at two concentrations of $\mathrm{Zn}$.

\section{MATERIALS AND METHODS}

The seeds of parsely plant (Petroselinum crispum Mill. var. neapolitanum) was achieved from the Agricultural Research Center of Tabriz, Iran.

\subsection{Plants growth condition}

Plants were grown hydroponically in a growth chamber with a temperature of $28 / 20^{\circ} \mathrm{C}, 16 \mathrm{~h}$ photoperiod and relative humidity of $70 \%$. Seeds were germinated in petri-dishes and transferred to plastic containers with 21 of Cooper nutrient solution (50\%) and pre-cultured for 7 days. After pre-culturing period plants were transferred to the full strength nutrient solution, containing two levels of $\mathrm{Zn}(1.5$ and $6.5 \mu \mathrm{m})$ as zinc sulphate. Applied UV doses that were received by one-half of plants were 20.5 and $176 \mathrm{~kJ} \mathrm{~m}^{-2}$ day $^{-1}$ for UVA and UVB respectively (supplied with $30 \mathrm{~W}$, UV lamps, Philips; UVA $30 \%$, UVB 5\%). 20 days after treatments, the plants were harvested and stored in $80{ }^{\circ} \mathrm{C}$ for further analyses.

\subsection{Photosynthetic pigments and phytochemicals assays}

Fresh leaf tissues were homogenized with $80 \%$ aqueous acetone. The extracts were centrifuged for $10 \mathrm{~min}$ at 4000 g. Chlorophylls and carotenoids contents were determined spectrophotometrically at 470, 646.8 and $663.2 \mathrm{~nm}$ using equations described by Lichtenthaler (1987).

Anthocyanins were extracted with acidified methanol (methanol: $\mathrm{HCl}, 99: 1, \mathrm{v} / \mathrm{v}$ ) solution on a shaker in the dark at $4{ }^{\circ} \mathrm{C}$ per $48 \mathrm{~h}$. After filtering, the absorbance of samples were measured spectrophotometrically at $550 \mathrm{~nm}$ and calculated using an extinction coefficient of $33000 \mathrm{~mol}^{-1} \mathrm{~cm}^{-1}$ (Wagner, 1979).

Total phenolic of shoots was extracted by $80 \%$ aqueous methanol for $20 \mathrm{~min}$ using ultrasonic bath. The mixture was centrifuged at $14000 \mathrm{~g}$ for $5 \mathrm{~min}$.To $0.5 \mathrm{ml}$ of supernatant, $1.5 \mathrm{ml}(1: 10 \mathrm{v} / \mathrm{v}$ diluted with distilled water) Folin-Ciocalteau reagent was added and allowed to stand for $5 \mathrm{~min}$ at $22^{\circ} \mathrm{C}$. After $5 \mathrm{~min}, 2 \mathrm{ml}$ of $7.5 \%$ of sodium carbonate was added. These mixtures were incubated for $90 \mathrm{~min}$ in the dark with intermittent shaking. After incubation, development of blue color was measured at $725 \mathrm{~nm}$. The phenolic content was calculated on the basis of standard curve of gallic acid (Fletcher and Kott, 1999).

The total flavonoid content of shoots was determined using the aluminum chloride assay through colorimetry. An aliquot $(1 \mathrm{ml})$ of extracts were taken in different test tubes then $6 \mathrm{ml}$ of distilled water was added followed by the addition of $0.3 \mathrm{ml}$ of sodium nitrite $\left(5 \% \mathrm{NaNO}_{2}\right.$, $\mathrm{w} / \mathrm{v}$ ) and allowed to stand for $6 \mathrm{~min}$. Later $0.3 \mathrm{ml}$ of aluminum trichloride $\left(10 \% \mathrm{AlCl}_{3}\right)$ was added and incubated for $6 \mathrm{~min}$, followed by the addition of $2 \mathrm{ml}$ of sodium hydroxide $(\mathrm{NaOH}, 4 \% \mathrm{w} / \mathrm{v})$. After $15 \mathrm{~min}$ of incubation the mixture turns to pink and its absorbance was measured at $510 \mathrm{~nm}$. The total flavonoid content was calculated on the basis of standard curve of quercitine (Toor and Savage, 2005).

\subsection{Antioxidant enzymes assays}

To obtain the crude extract, $0.1 \mathrm{~g}$ parsley leaves were homogenized in $3 \mathrm{ml}$ of $10 \mathrm{mmol} \mathrm{l}^{-1}$ potassium phosphate buffer $(\mathrm{pH}=7)$, containing $0.2 \%$ polyvinyl pyrrolidone. The homogenate was centrifuged at $21,000 \mathrm{~g}$ at $4{ }^{\circ} \mathrm{C}$ for $20 \mathrm{~min}$. The resulting supernatant was used to measure the activities of superoxide dismutase (SOD), peroxidase (POD) and catalase (CAT) and protein content. The activity of SOD was measured according to its capacity to inhibit photochemical reduction of nitroblue tetrazolium. The reaction mixture contained $2.65 \mathrm{ml}$ of $67 \mathrm{mmol} \mathrm{l}^{-}$ ${ }^{1}$ potassium phosphate buffer $(\mathrm{pH}=7.8), 0.2 \mathrm{ml}$ of $0.1 \mathrm{mmol} \mathrm{l}^{-1}$ EDTA solution containing $0.3 \mathrm{mmol} \mathrm{l}^{-1}$ sodium cyanide, $0.1 \mathrm{ml}$ of $1.5 \mathrm{mmol} \mathrm{l^{-1 }} \mathrm{NBT}, 50 \mathrm{ml}$ of $0.12 \mathrm{mmol} \mathrm{l}^{-1}$ riboflavin and $50 \mathrm{ml}$ enzyme extract. The amount of enzyme that catalyzed $50 \%$ inhibition from photochemical reduction of NBT was defined as one unit (U) of SOD. Due to the possibility of autooxidation of the substrates, control assays were prepared in the absence of plant extract (Winterbourn et al., 1976).

Guaiacol POD was assayed in plant shoots, following the method of Chance and Maehly (1955). The reaction 
mixture contained $1.50 \mathrm{ml}$ of $100 \mathrm{mmol}^{-1}$ citratephosphate - borate buffer solution $(\mathrm{pH}=7.5), 50 \mu \mathrm{l}$ of $15 \mathrm{mmol} \mathrm{l}^{-1}$ guaiacol, $25 \mu \mathrm{l}$ enzyme extract and $50 \mu \mathrm{l}$ of $3.3 \mathrm{mmol} \mathrm{l}^{-1} \mathrm{H}_{2} \mathrm{O}_{2}$. The polymerization of guaiacol was initiated by adding $\mathrm{H}_{2} \mathrm{O}_{2}$ and an increase in absorbance at $470 \mathrm{~nm}$ was recorded for $3 \mathrm{~min}$. POD activity was calculated using the extinction coefficient, 26.6 ( $\mathrm{mmol} \mathrm{l}^{-}$ $\left.{ }^{1}\right)^{-1} \mathrm{~cm}^{-1}$, for guaiacol. The generation of $1 \mu \mathrm{mol}$ of tetra guaiacol per min was catalyzed by the amount of enzyme that was introduced as one unit of POD.

The CAT activity was determined by monitoring the decrease in absorbance at $240 \mathrm{~nm}$ for $3 \mathrm{~min}$ due to dismutation of $\mathrm{H}_{2} \mathrm{O}_{2}$. The reaction mixture contained $1.50 \mathrm{ml}$ of $100 \mathrm{mmol} \mathrm{l}^{-1}$ citrate-phosphate-borate buffer solution $(\mathrm{pH}=7.5), 50 \mu \mathrm{l}$ enzyme extract and $13 \mu \mathrm{l}$ of $10 \mathrm{mmol} \mathrm{1}^{-1} \mathrm{H}_{2} \mathrm{O}_{2}$. The amount of enzyme for dismutation of $1 \mu \mathrm{mol} \mathrm{l}^{-1} \mathrm{H}_{2} \mathrm{O}_{2}$ per min was expressed as one unit. Extinction coefficient for $\mathrm{H}_{2} \mathrm{O}_{2}$ at $240 \mathrm{~nm}$ was considered $39.4\left(\mathrm{mmol} \mathrm{l}^{-1}\right)^{-1} \mathrm{~cm}^{-1}$ (Obinger et al., 1997).

\subsection{Total proteins and soluble sugars}

Total protein content was measured by the method of Bradford (1976) using bovine serum albumin as a standard. The soluble sugars content was measured by DuBois et al. (1956) method.

\subsection{Hydrogen peroxide and malondialdehyde assays}

The hydrogen peroxide $\left(\mathrm{H}_{2} \mathrm{O}_{2}\right)$ content was estimated according to the Harinasut et al. (2003). Samples were homogenized with $0.1 \%(\mathrm{w} / \mathrm{v})$ trichloroaceticacid (TCA). Mixture was centrifuged at $12000 \mathrm{~g}$ for $15 \mathrm{~min}$. To $0.5 \mathrm{ml}$ of the supernatant, $0.5 \mathrm{ml}$ of $10 \mathrm{mM}$ phosphate buffer $(\mathrm{pH}=7.0)$ and $1 \mathrm{ml}$ of $1 \mathrm{~m}$ potassium iodide (KI) was added. The mixture was incubated at $25^{\circ} \mathrm{C}$ for $15 \mathrm{~min}$. The absorbance was measured at 390 nm. The $\mathrm{H}_{2} \mathrm{O}_{2}$ content was calculated from a standard curve prepared in a similar way.

Lipid peroxidation was estimated from the amount of malondialdehyde (MDA) formed in a reaction mixture (Heath and Packer, 1968). Leaf tissues were homogenized in $0.1 \%$ (w/v) (TCA). The homogenate was centrifuged at $10,000 \mathrm{~g}$ for $5 \mathrm{~min}$. To $1 \mathrm{ml}$ of the supernatant, $4 \mathrm{ml}$ of $20 \%$ TCA containing $0.5 \%$ thiobarbituric acid was added. The mixture was incubated at $95{ }^{\circ} \mathrm{C}$ in a water bath for $30 \mathrm{~min}$, and then quickly cooled on ice. The mixture was centrifuged at 10,000 $\mathrm{g}$ for $15 \mathrm{~min}$ and the absorbance was measured at $532 \mathrm{~nm}$. MDA levels were calculated from 1,1',3,3'tetra ethoxy propan standard curve.

\subsection{Statistical Analysis}

Experiment was conducted in complete randomized design with 3 replications. Analysis of variance was performed using InStat (3.0) software. The data were presented as the means \pm SE for each treatment. Means were compared with Tukey's Multiple Range Test at the $5 \%$ probability level.

\section{RESULTS AND DISCUSSION}

\subsection{Growth parameters}

In this study, UV radiation non significantly decreased the fresh and dry mass and lengths of parsley plants shoots and roots at both levels of applied $\mathrm{Zn}$. Application of $\mathrm{Zn}$ at concentration of $6.5 \mu \mathrm{m}$ significantly $(p<0.05)$ increased the dry and fresh mass of shoots (Fig 1), but non significantly increased the dry and fresh mass of roots (Fig 2) and plant length (Fig 3) in compared to plants received concentration of $1.5 \mu \mathrm{m}$ of $\mathrm{Zn}$ at normal and UV radiation conditions. The effect of UV radiation on plants growth is varying among different species. In the wide range of species, plant growth decreases in response to UV radiation, but in some cases the growth is not affected or it is even promoted by this radiation (Fedina et al., 2010, Ravindran et al., 2010; Zlatev et al., 2012). The induced changes in the plant's growth regulators biosynthesis and transport by UV radiation are responsible for the decreased growth of plants (Toosi et al., 2009). Similar to results obtained from this study, the biomass and production of potato, clover, oat and barley plants did not dramatically affect by $24-33 \%$ increases in UV radiation during the growing season (Hakala et al., 2002). The ability of plant in the prevention of growth reduction under UV treatment is an indicator for plant tolerance (Smith et al., 2000). In this study, the application of $\mathrm{Zn}$ at high concentration could improve the growth of parsley under normal condition and UV radiation. The beneficial effects of $\mathrm{Zn}$ on plants growth are related to its necessity for carbohydrate and protein metabolism, membrane integrity, auxin synthesis and reproduction (Alloway, 2008). 


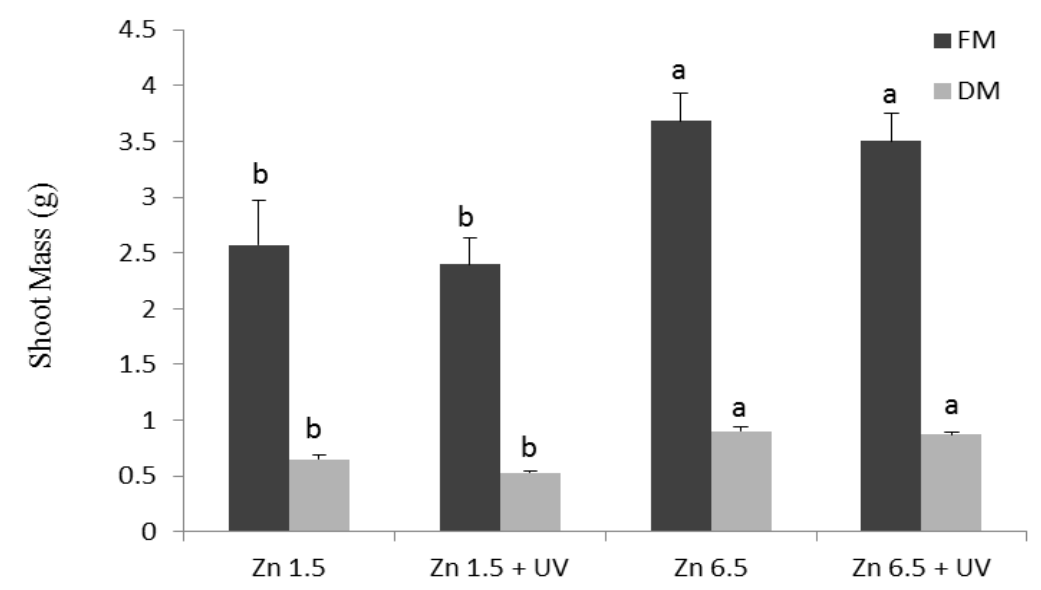

Figure 1: Effect of UV treatment on the fresh and dry mass of parsley shoots under different concentrations of $\mathrm{Zn}$

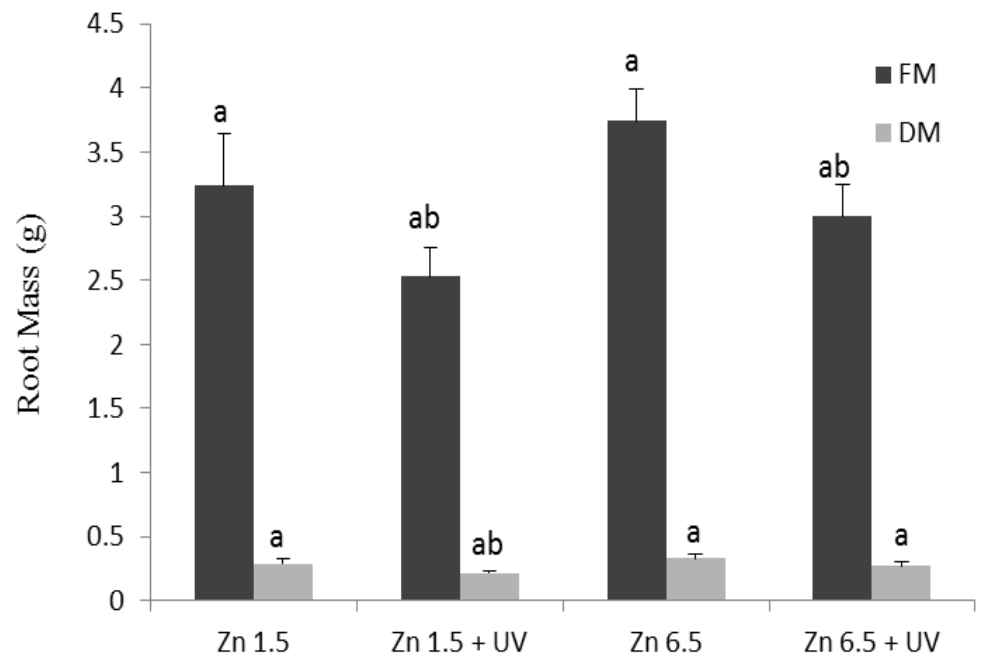

Figure 2: Effect of UV treatment on the fresh and dry mass of parsley roots under different concentrations of $\mathrm{Zn}$

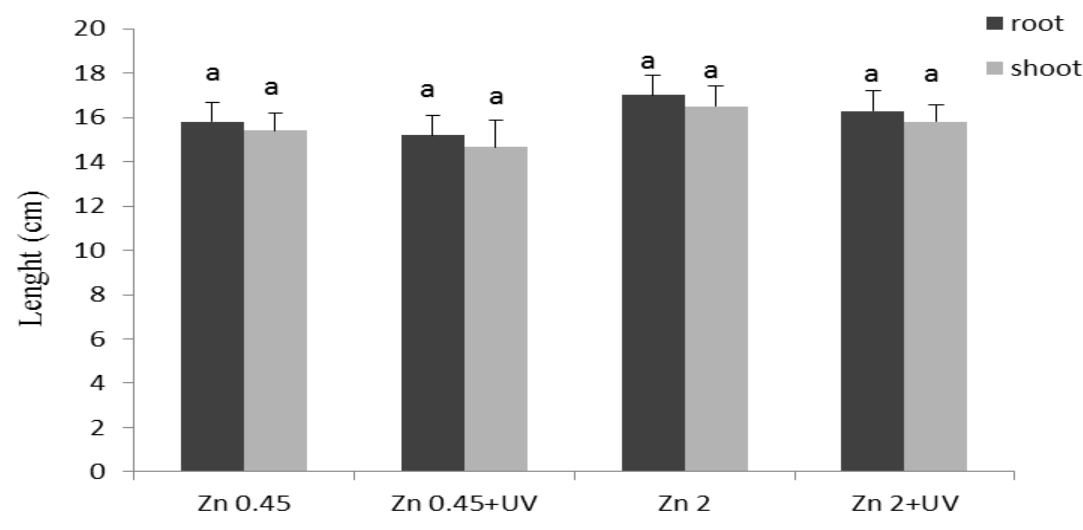

Figure 3: Effect of UV treatment on the length of parsley shoots and roots under different concentrations of $\mathrm{Zn}$

\subsection{Photosynthetic pigments}

The concentrations of chlorophylls $\mathrm{a}, \mathrm{b}$ and total were not significantly affected by UV treatment and $\mathrm{Zn}$ concentrations. But, carotenoids content and carotenoid/chlorophyll ratio of UV treated plants increased significantly $(p<0.05)$ in both concentrations of $\mathrm{Zn}$. Application of $\mathrm{Zn}$ at concentration of $6.5 \mu \mathrm{m}$ slightly increased the carotenoid content and carotenoid/chlorophyll ratio of plants compared to the concentration of $1.5 \mu \mathrm{m}$ of $\mathrm{Zn}$ in both conditions (Table 
1). According to results obtained from this study, parsley plant could effectively protects its own chlorophyll content against the enhanced UVA + B radiation by increasing the carotenoids content in both levels of Zn. Similar to this study, Salama et al. (2011) reported that in Rumex vesicarius L. the chlorophyll content of plant was not affected notably by UV treatment. The carotenoids are involved in the photosynthetic structures protection against the destructive effects of UV radiation (Nasibi and Kalantari, 2005). The efficacy of carotenoids in protecting the photosystems is likely due to their function as efficient quenchers of high energy of short wave radiation. The plant capacity in the protection of photosynthetic pigments content under enhanced UV conditions restores plant photosynthesis rate and tolerates plant against this stress (Levall and Bornman, 2006; Reshmi and Rajalakshmi, 2012). Zn application in this study did not affect the chlorophylls contents of parsley plant significantly. Similar to this result are those obtained for maize plants at different concentrations of $\mathrm{Zn}$ under the condition without stress (Saeidnejad and Kafi, 2013).

Table 1: Effect of UV treatment on photosynthetic pigments of parsley plant under different concentrations of $\mathrm{Zn}$

\begin{tabular}{lccccc}
\hline treatment & $\begin{array}{c}\text { Chlorophyll a } \\
\left(\mathrm{mg} \mathrm{g}^{-1} \mathrm{FM}\right)\end{array}$ & $\begin{array}{c}\text { Chlorophyll b } \\
\left(\mathrm{mg} \mathrm{g}^{-1} \mathrm{FM}\right)\end{array}$ & $\begin{array}{c}\text { Total chlorophyll } \\
\left(\mathrm{mg} \mathrm{g}^{-1} \mathrm{FM}\right)\end{array}$ & $\begin{array}{c}\text { Carotenoid } \\
\left(\mathrm{mg} \mathrm{g}^{-1} \mathrm{FM}\right)\end{array}$ & $\begin{array}{c}\text { Carotenoid/ } \\
\text { chlorophyll }\end{array}$ \\
\hline $\mathrm{Zn} 1.5 \mu \mathrm{m}$ & $0.14 \pm 2.53 \mathrm{a}$ & $0.48 \pm 3.07 \mathrm{a}$ & $0.15 \pm 5.93 \mathrm{a}$ & $0.11 \pm 0.31 \mathrm{~b}$ & $0.01 \pm 0.05 \mathrm{bc}$ \\
$\mathrm{Zn} 1.5 \mu \mathrm{m}+\mathrm{UV}$ & $0.04 \pm 2.63 \mathrm{a}$ & $0.09 \pm 2.34 \mathrm{a}$ & $0.34 \pm 5.15 \mathrm{a}$ & $0.97 \pm 3.027 \mathrm{a}$ & $0.07 \pm 0.48 \mathrm{a}$ \\
$\mathrm{Zn} 6.5 \mu \mathrm{m}$ & $0.031 \pm 2.59 \mathrm{a}$ & $3.33 \pm 0.12 \mathrm{a}$ & $0.6 \pm 5.95 \mathrm{a}$ & $0.19 \pm 0.54 \mathrm{~b}$ & $0.09 \pm 0.07 \mathrm{~b}$ \\
$\mathrm{Zn} 6.5 \mu \mathrm{m}+\mathrm{UV}$ & $0.07 \pm 2.55 \mathrm{a}$ & $0.27 \pm 3.1 \mathrm{a}$ & $0.41 \pm 5.64 \mathrm{a}$ & $0.65 \pm 3.44 \mathrm{a}$ & $0.08 \pm 0.6 \mathrm{a}$ \\
\hline
\end{tabular}

Each value represented as mean $\pm \mathrm{SE}(\mathrm{n}=3)$; mean values followed by the same letter (s) are not significantly different $(p<0.05)$.

\subsection{Phenolic compounds}

UV treatment induced a significant increase in the anthocyanin content of parsley plants at concentration of $1.5 \mu \mathrm{m}$ of $\mathrm{Zn}$, but a slight increase was seen at concentration of $6.5 \mu \mathrm{m}$ of $\mathrm{Zn}$. The flavonoids concentration of plants significantly $(p<0.05)$ increased by UV treatment in both levels of applied $\mathrm{Zn}$. There were some increases in the total phenols contents of plants treated with UV at both levels of $\mathrm{Zn}$ wich they were not significant. In normal conditions without UV radiation, application of $\mathrm{Zn}$ at concentration of $6.5 \mu \mathrm{m}$ caused non-significant increase in these parameters compared to the concentration of $1.5 \mu$ mof $\mathrm{Zn}$ (Table 2). The increased level of UV absorbing phenolics is the common protective response to enhanced UV radiation in plant species (Reshmi and Rajalakshmi, 2012; Wei et al., 2013). It has been demonstrated that UV-B photoreceptor, UV RESISTANCE LOCUS8 protein (gene name: UVR8), absorbs UV-B light through conserved tryptophan residues (Mach, 2016). Absorbing UV-B causes the apparent UVR8 homodimer to dissociate into monomers, which interact with constitutively photomorphogenic1 (COP1), an E3 ubiquitin ligase (Rizzini et al., 2011). This interaction induces genes encoding protective factors such as phenylpropanoid biosynthesis pathway, and damagerepair factors such as photolyases (Fasano et al., 2014). Furthermore, the role of phenolic compounds as a product of phenyl propanoid pathway in the free radicals scavenging was also proved (Nasibi and Kalantari, 2005). It was proposed that plants with low levels of phenolic compounds are sensitive to UV radiation (Kim and Rodrigo, 2001; Zlatev et al., 2012). In this study, application of concentration of $6.5 \mu$ mof $\mathrm{Zn}$ increased the phenolic compounds compared to $1.5 \mu \mathrm{m}$. Our results about the positive effect of $\mathrm{Zn}$ application on biosynthesis of phenolic compounds is parallel to that reported for Pistacia vera L. by Tavllali et al. (2010) under saline condition.

\subsection{Total proteins and soluble sugars}

Total proteins and soluble sugars contents of UV treated plants decreased significantly $(p<0.05)$ in plants which received $1.5 \mu \mathrm{m}$ of $\mathrm{Zn}$, but the induced decreases in total proteins and soluble sugars in plants received 6.5 $\mu \mathrm{m}$ of $\mathrm{Zn}$ were not significant. At normal condition there was no main difference in these parameters between two levels of applied $\mathrm{Zn}$ (Table 2). The reductive effect of UV radiation on protein content is related to direct DNA injury, amino acid destruction and proteins and enzymes inactivation induced by UV radiation (Salama et al., 2011; Zlatev et al., 2012). Moreover, UV radiation causes the detrimental effects in the structure of RNA molecules and thus disrupts protein synthesis (Ulm and Nagy, 2005). According to this study, zinc application at high concentration in 
UVA + B treated plants increased the protein content. The beneficial effect of $\mathrm{Zn}$ application on the protein content was reported for many species such as wheat plants under stress conditions (Morshedi and Farahbakhsh, 2010). Zn is necessary for the activity of the enzyme RNA polymerase and it protects the ribosomal RNA from attack by the enzyme ribonuclease. It is proposed that the most fundamental effect of zinc on protein metabolism is through its involvement in the stability and function of genetic material (Alloway, 2008).

The results attained for soluble sugars in this study were parallel to that obtained for total protein content. It has been proposed that UV radiation by inactivation the photosynthetic enzymes such as rubisco and some other Calvin cycle enzymes and damaging the photosystem II proteins adversely affects the photosynthesis and decreases the sugar synthesis ( $\mathrm{Zu}$ et al., 2004; Zlatev et al., 2012). In this study, the induced reduction in soluble sugars by UVA + B treatment was not significant at sufficient amounts of $\mathrm{Zn}$. The positive effect of $\mathrm{Zn}$ application on soluble sugar content probably is related to its role in protection of photosynthetic enzymes from UV damages and contribution in the structure of enzyme ribulose bisphosphat carboxylase (Alloway, 2008). The enhanced amounts of soluble sugars by sufficient $\mathrm{Zn}$ application was reported for different plant species such as Cucurbita pepo L. under stressful and normal conditions (Sorkhi Lalelou et al., 2013).

Table 2: Effect of UV treatment on anthocyanins, total phenolics, flavonoids, soluble sugars and total protein contents of parsley plant under different concentrations of $\mathrm{Zn}$

\begin{tabular}{llllll}
\hline treatment & $\begin{array}{l}\text { Anthocyanins } \\
\left(\mathrm{mg} \mathrm{g}^{-1} \mathrm{FM}\right)\end{array}$ & $\begin{array}{l}\text { Flavonoids } \\
\left(\mathrm{mg} \mathrm{g}^{-1} \mathrm{FM}\right)\end{array}$ & $\begin{array}{l}\text { Total phenols } \\
\left(\mathrm{mg} \mathrm{g}^{-1} \mathrm{FM}\right)\end{array}$ & $\begin{array}{l}\text { Soluble sugars } \\
\left(\mathrm{mg} \mathrm{g}^{-1} \mathrm{DM}\right)\end{array}$ & $\begin{array}{l}\text { Total protein } \\
\left(\mathrm{mg} \mathrm{g}^{-1} \mathrm{FM}\right)\end{array}$ \\
\hline $\mathrm{Zn} 1.5 \mu \mathrm{m}$ & $1.4 \pm 0.08 \mathrm{~b}$ & $1.35 \pm 0.082 \mathrm{~b}$ & $8.61 \pm 0.7 \mathrm{~b}$ & $109.8 \pm 3.63 \mathrm{a}$ & $27.6 \pm 0.59 \mathrm{a}$ \\
$\mathrm{Zn} 1.5 \mu \mathrm{m}+\mathrm{UV}$ & $1.94 \pm 0.07 \mathrm{a}$ & $2.53 \pm 0.32 \mathrm{a}$ & $14.32 \pm 0.12 \mathrm{ab}$ & $79.1 \pm 2.7 \mathrm{~b}$ & $25.4 \pm 0.21 \mathrm{~b}$ \\
$\mathrm{Zn} 6.5 \mu \mathrm{m}$ & $1.47 \pm 0.06 \mathrm{~b}$ & $1.39 \pm 0.09 \mathrm{~b}$ & $10.43 \pm 0.7 \mathrm{ab}$ & $111.8 \pm 4.23 \mathrm{a}$ & $28.7 \pm 0.44 \mathrm{a}$ \\
$\mathrm{Zn} 6.5 \mu \mathrm{m}+\mathrm{UV}$ & $1.51 \pm 0.045 \mathrm{ab}$ & $2.62 \pm 0.22 \mathrm{a}$ & $16.11 \pm 0.1 \mathrm{a}$ & $96.8 \pm 6.3 \mathrm{a}$ & $26.53 \pm 0.38 \mathrm{a}$ \\
\hline
\end{tabular}

Each value represented as mean $\pm \mathrm{SE}(\mathrm{n}=3)$; mean values followed by the same letter (s) are not significantly different $(p<0.05)$.

\subsection{Antioxidant system}

In this study, UV treatment significantly $(p<0.05)$ increased the activities of POD and CAT enzymes, but slightly decreased the activity of SOD enzyme at concentration of $1.5 \mu \mathrm{m}$ of $\mathrm{Zn}$. In plants received the concentration of $6.5 \mu$ mof $\mathrm{Zn}$, UV treatment had no significant effect on the activities of SOD and POD, but significantly increased the CAT activity. In the conditions with no UV radiation, application of $6.5 \mu \mathrm{m}$ of $\mathrm{Zn}$ could increase the SOD activity of plants compared to $1.5 \mu \mathrm{m} \mathrm{Zn}$, but did not affect the POD and CAT activities considerably (Table 3 ).

$\mathrm{H}_{2} \mathrm{O}_{2}$ content of plants significantly $(p<0.05)$ increased in response to UV treatment in both levels of Zn. UV treated plants that received the concentration of $1.5 \mu \mathrm{m}$ of $\mathrm{Zn}$ had the highest amounts of $\mathrm{H}_{2} \mathrm{O}_{2}$. Under condition without UV radiation, plants received $6.5 \mu \mathrm{m}$ of $\mathrm{Zn}$ had slightly lower amount of $\mathrm{H}_{2} \mathrm{O}_{2}$ compared to plants which received $1.5 \mu \mathrm{m}$ of this element. The MDH content of plants increased significantly only in the UV treated plants which received $1.5 \mu \mathrm{m}$ of $\mathrm{Zn}$. In the plants fed with concentration of $6.5 \mu \mathrm{m}$ of $\mathrm{Zn}$, UV could not enhance this metabolite considerably (Table 3). UV radiation induces oxidative stress in plants (Hakala et al., 2002; Tossi et al., 2009). The increased levels of ROS in plants damage biomolecules such as lipids and result to MDA formation as the breakdown product of polyunsaturated fatty acids of membranes. The effect of sufficient $\mathrm{Zn}$ application on controlling the production of these detrimental components was reported by authors in different full stress conditions (Tavallali et al., 2010; Weisany et al., 2012), but there is no available reference concerning role of this element under UV condition. Zinc plays a key role in controlling the generation and detoxification of free oxygen radicals and subsequent lipid membrane oxidation (Alloway, 2008). It has been demonstrated that $\mathrm{Zn}$ ions have strong inhibitory effect on membrane bound NADPH oxidase (Cakmak and Marschner, 1988; Kawano et al., 2002). 
The activities of antioxidant enzymes POD and CAT in UV treated plants increased in this study. The enhancement in the activities of these enzymes in response to UV-B treatment were reported by several authors (Nasibi and Kalantari, 2005; Czégény et al., 2016). Antioxidant enzymes play a significant role in the dynamic equilibration between free oxygen radicals production and destruction. The responses of antioxidant enzymes to UV radiation vary among plants species (Tossi et al., 2009; Salama et al., 2011; Czégény et al., 2016). The increasing in the activities of antioxidant enzymes could be the indicator of build-up of a protective mechanism to reduce oxidative damages induced by stress (Harinasut et al., 2003; Chawla et al., 2013). According to results obtained from this study, the produced $\mathrm{H}_{2} \mathrm{O}_{2}$ effectively removed by POD and especially CAT in plants fed with concentration of 6.5 $\mu \mathrm{m} \mathrm{Zn}$. There was a small decrease in the activity of SOD enzyme in response to UV treatment in parsley plant in low level of applied $\mathrm{Zn}$ that was improved by application of $6.5 \mu \mathrm{m}$ of $\mathrm{Zn}$. Reduction in the activity of SOD enzyme as a result of UV-B radiation has been reported for sun flower plant (Costa et al., 2002). It has been proposed that a high amount of $\mathrm{H}_{2} \mathrm{O}_{2}$ is able to inhibit $\mathrm{Cu}-\mathrm{Zn}-\mathrm{SOD}$ via the reduction of $\mathrm{Cu}^{2+}$ to $\mathrm{Cu}^{+}$ (Casano et al. 1997). $\mathrm{Zn}$ is able to facilitate the biosynthesis of antioxidant enzymes (Cakmak, 2000) and its effects on improvement of antioxidant system of plants under various stresses have reported by several authors (Tavallali et al., 2010; Weiasany et al., 2012; Michael and Krishnaswamy, 2014).

Table 3: Effect of UV treatment on antioxidant enzymes activities that defined as unit (U) and $\mathrm{MDH}$ and $\mathrm{H}_{2} \mathrm{O}_{2}$ contents of parsley plant under different concentrations of $\mathrm{Zn}$

\begin{tabular}{|c|c|c|c|c|c|}
\hline treatment & $\begin{array}{c}\text { SOD activity } \\
\left(\mathrm{U} \mathrm{mg}^{-1} \text { pro } \mathrm{min}^{-1}\right)\end{array}$ & $\begin{array}{c}\text { POD activity } \\
\left(\mathrm{U} \mathrm{mg}^{-1} \text { pro } \mathrm{min}^{-1}\right)\end{array}$ & $\begin{array}{c}\text { CAT activity } \\
\left(\mathrm{U} \mathrm{mg}^{-1} \text { pro } \text { min }^{-1}\right)\end{array}$ & $\begin{array}{c}\mathrm{H}_{2} \mathrm{O}_{2} \\
\left(\mu \mathrm{mol} \mathrm{g}{ }^{-1} \mathrm{FM}\right)\end{array}$ & $\begin{array}{c}\text { MDA } \\
\left(\mathrm{nmol} \mathrm{g}^{-1} \mathrm{FM}\right)\end{array}$ \\
\hline $\mathrm{Zn} 1.5 \mu \mathrm{m}$ & $0.4 \pm 0.03 \mathrm{ab}$ & $0.12 \pm 0.09 \mathrm{~b}$ & $0.45 \pm 0.007 \mathrm{~b}$ & $0.096 \pm 0.005 \mathrm{c}$ & $1.74 \pm 0.097 \mathrm{~b}$ \\
\hline $\mathrm{Zn} 1.5 \mu \mathrm{m}+\mathrm{UV}$ & $0.3 \pm 0.015 b$ & $0.25 \pm 0.04 \mathrm{a}$ & $1.3 \pm 0.045 \mathrm{a}$ & $0.23 \pm 0.023 \mathrm{a}$ & $5.57 \pm 1.11 \mathrm{a}$ \\
\hline $\mathrm{Zn} 6.5 \mu \mathrm{m}$ & $0.47 \pm 0.07 \mathrm{a}$ & $0.17 \pm 0.06 \mathrm{~b}$ & $0.42 \pm 0.09 \mathrm{~b}$ & $0.088 \pm 0.003 \mathrm{c}$ & $1.64 \pm 0.017 \mathrm{~b}$ \\
\hline $\mathrm{Zn} 6.5 \mu \mathrm{m}+\mathrm{UV}$ & $0.5 \pm 0.04 \mathrm{a}$ & $0.19 \pm 0.02 b$ & $1.5 \pm 0.029 \mathrm{a}$ & $0.18 \pm 0.01 b$ & $2.7 \pm 0.5 \mathrm{~b}$ \\
\hline
\end{tabular}

Each value represented as mean \pm SE $(n=3)$; mean values followed by the same letter (s) are not significantly different $(p<0.05)$.

\section{CONCLUSIONS}

The results of this study showed the relative tolerance of parsley plant against applied doses of UV radiation at both concentrations of $\mathrm{Zn}$, but it was more obvious at concentration of $6.5 \mu \mathrm{m}$. This plant could effectively increase UV absorbing phenolic compounds and carotenoids in response to UV radiation that are involved in photosynthetic apparatus protection.
Moreover the induced increases in the activities of antioxidant enzymes in UV treated plants are responsible to moderate the ROS production in this plant. According to results obtained from this study, Zn application at concentration of $6.5 \mu \mathrm{m}$ had positive effects on parsley resistance to UV radiation.

\section{ACKNOWLEDGEMENTS}

The authors would like to express their sincere appreciation to Dr. Rogieh Haji-Boland, University of
Tabriz, Faculty of sciences, for supply of laboratory equipment.

\section{REFERENCES}

Alloway, B. J. (2008). Zinc in Soils and Crop Nutrition. Brussels, Belgium and Paris, IZA \& IFA.

Bradford, M. (1976). A rapid and sensitive method for the quantitation of microgram quantities of protein utilizing the principle of protein-dye binding. Annual Review of Biochemistry, 72(1-2), 248-254. doi:10.1016/0003-2697(76)90527-3 
Cakmak, I. (2000). Tansley review no. 111. New Phytologist, 146(2), 185-205. doi:10.1046/j.14698137.2000.00630.x

Cakmak, I., Marschner, H. (1988). Increase in membrane permeability and exudation in roots of zinc deficient plants. Journal of Plant Physiology, 132(3), 356-361. doi:10.1016/S0176-1617(88)80120-2

Casano, L., Gomez, L., Lascano, C., Trippi, V. (1997). Inactivation and degradation of $\mathrm{Cu} / \mathrm{Zn}-\mathrm{SOD}$ by active oxygen species in wheat chloroplasts exposed to photooxidative stress. Plant and Cell Physiology, $38(4)$, doi:10.1093/oxfordjournals.pcp.a029186

Chance, B., Maehly, A. C. (1955). Assay of catalases and peroxidases, Methods in Enzymology. New York, NY: Academic Press.

Chawla, S., Jain, S., Jain, V. (2013). Salinity induced oxidative stress and antioxidant system in salt-tolerant and salt-sensitive cultivars of rice (Oryza sativa L.). Journal of Plant Biochemistry and Biotechnology, 22(1), 27-34. doi:10.1007/s13562-012-0107-4

Cooper, A. (1988). 1. The system. 2. Operation of the system. In G. Books (ed), The ABC of Nutrient Film Technique (pp. 3-123). England, UK: Intl Specialized Book Service Inc.

Costa, H., Gallego, S. M., Tomaro, M. A. L. (2002). Effect of UV-B radiation on antioxidant defense system in sunflower cotyledons.Plant Science, 162(6), 939-945. doi:10.1016/S0168-9452(02)00051-1

Czégény, G., Mátai,A., Hideg,É. (2016). UV-B effects on leaves-oxidative stress and acclimation in controlled environments. Plant Science, 248, 57-63. doi:10.1016/j.plantsci.2016.04.013

DuBois, M., Gilles, K. A., Hamilton, J. K., Rebers P. A., Smith, F. (1956). Colorometric method for determination of sugars and related substances. Anals of Chemistry, 28(3), 350-356. doi:10.1021/ac60111a017

Eichholz, I., Huyskens-Keil, S., Keller, A., Ulrich, D., Kroh, L. W., Rohn, S. ( 2011). UV-B-induced changes of volatile metabolites and phenolic compounds in blueberries (Vaccinium corymbosum L.). Food Chemistry, 126(1), 60-64. doi:10.1016/j.foodchem.2010.10.071

Fasano, R., Gonzalez, N., Tosco, A., Piaz, F. D., Docimo, T., Serrano, R., Grillo, S., Leone, A., Inzé, D. (2014).Role of Arabidopsis UV RESISTANCE LOCUS 8 in plant growth reduction under osmotic stress and lowlevels of UV-B. Molecular Plant, 7(5), 773-791. doi:10.1093/mp/ssu002

Fedina, I., Hidema, J., Velitchkova, M., Georgieva, K., Nedeva, D. (2010). UV-B induced stress responses in three rice cultivars. Biologia Plantarum, 54(3), 571574. doi:10.1007/s10535-010-0102-3
Fletcher, R. S., Kott, L. S. (1999). Phenolics and cold tolerance of Brassica napus. Plant Agriculture, 1, 1-5.

Hakala, K., Jauhiainen, L., Koskela, T., Käyhkö, P., Vorne, V. (2002). Sensitivity of crops to increased ultraviolet radiation in northern growing conditions. Journal of Agronomy and Crop Science, 188(1), 8-18. doi:10.1046/j.1439-037x.2002.00536.x

Harinasut, P., Poonsopa, D., Roengmongkol, K., Charoensataporn, R. (2003). Salinity effects on antioxidant enzymes in mulberry cultivar. ScienceAsia, 29, 109-113. doi:10.2306/scienceasia1513-1874.2003.29.109

Hassan, M. J., Zhang, G., Wu, F., Wei, K., Chen, Z. (2005). Zinc alleviates growth inhibition and oxidative stress caused by cadmium in rice. Journal of Plant Nutrition and Soil Science, 168(2), 255-261. doi:10.1002/jpln.200420403

Heath, R. L., Packer, L. (1968). Photoperoxidation in isolated chloroplasts, I. Kinetics and stoichiometry of fatty acid peroxidation. Archives of Biochemistry and Biophysics, 125(1), 189-198. doi:10.1016/00039861(68)90654-1

Kawano, T., Kawano, N., Muto, S., Lapeyrie, F. (2002). Retardation and inhibition of the cation-induced superoxide generation in BY-2 tobacco cell suspension culture by $\mathrm{Zn}^{2+}$ and $\mathrm{Mn}^{2+}$. Physiologia Plantarum, 114(3), 395-404. doi:10.1034/j.13993054.2002.1140309.x

Kim, B., Rodrigo, L. (2001). Arabidopsis mutant tolerant to lethal ultraviolet-B levels shows constitutively elevated accumulation of flavonoids and other phenolics. Plant Physiology,126(3), 1105-1115. doi:10.1104/pp.126.3.1105

Levall, M., Bornman, J. F. (2006). Selection in vitro for UV-tolerant sugar beet (Beta vulgaris) somaclones. Physiologia Plantarum, 88(1), 37-43. doi:10.1111/j.1399-3054.1993.tb01757.x

Lichtenthaler, H. K. (1987). Chlorophylls and carotenoids, Pigments of photosynthetic biomembranes. Methods in Enzymology, 148, 350-382. doi:10.1016/00766879(87)48036-1

Mach, J. (2016). How plants take the bad with the good, conserved UV-B perception and signaling in Chlamydomonas. Plant Cell, 28(4), 825. doi:10.1105/tpc.16.00279

Mahdavian, K., Ghorbanli, M., Kalantari, K. M. (2008). The Effects of ultraviolet radiation on the contents of chlorophyll, flavonoid, anthocyanin and proline in Capsicum annuum L. Turkish Journal of Botany, 32, 25-33.

Michael, P. I., Krishnaswamy, M. (2014). Membrane damage and activity of antioxidant enzymes in response to zinc and high irradiance stress in cowpea 
$\mathrm{UVA}+\mathrm{B}$ treatment affects antioxidant system and phytochemicals of parsley plant under different concentrations of Zn

plant. International Journal of Current Research and Academic Review, 2(10), 112-128.

Morshedi, A., Farahbakhsh, H. (2010). Effects of potassium and zinc on grain protein contents and yield of two wheat genotypes under soil and water salinity and alkalinity stresses. Plant Ecophysiology, 2, 67-72.

Nasibi, F., Kalantari, K. M. (2005). The effects of UV-A, UV-B and UV-C on protein and ascorbate content, lipid peroxidation and biosynthesis of screening compounds in brassica napus. Iranian journal of science and technology transaction a- science, 29(A1), 39-48.

Obinger, C., Maj, M., Nicholls, P., Loewen, P. (1997). Activity, peroxide compound formation, and heme d synthesis in Escherichia coli HPII catalase. Archives of Biochemistry and Biophysics, 342(1), 58-67. doi:10.1006/abbi.1997.9988

Ravindran, K. C., Indrajith, A., Pratheesh, P. V., Sanjiviraja, K., Balakrishnan, V. (2010). Effect of ultraviolet-B radiation on biochemical and antioxidant defense system in Indigofera tinctoria L. seedlings.International Journal of Engineering, Science and Technology, 2(5), 226-232. doi:10.4314/ijest.v2i5.60154

Reshmi, G. R., Rajalakshmi, R. (2012). Drought and UV stress response in Spilanthes acmellaMurr. (toothache plant). Journal of Stress Physiology and Biochemistry, 8(4), 110-129.

Rizzini, L., Favory, J. J., Cloix, C., Faggionato, D., O'Hara, A., Kaiserli, E., Baumeister, R., et al. (2011). Perception of UV-B by the arabidopsis UVR8 protein. Science, 332(6025),

103-106. doi: $10.1126 /$ science. 1200660

Saeidnejad, A. H., Kafi, M. (2013). Alleviative effects of Zinc on physiological properties and antioxidants activity of maize plants under salinity stress. International Journal of Agriculture and Crop Sciences, 5(5), 529-537.

Salama, H. M. H., Al-Watban, A. A., Al-Fughom, A. T. (2011). Effect of ultraviolet radiation on chlorophyll, carotenoid, protein and proline contents of some annual desert plants. Saudi Journal of Biological Sciences, 18(1), 79-86. doi:10.1016/j.sjbs.2010.10.002

Smith, J. L., Burritt, D. J., Bannister, P. (2000). Shoot dry weight, chlorophyll and UV-B- absorbing compounds as indicators of a plant's sensitivity to UV-B radiation. Annals of Botany, 86(6), 1057-1063. doi:10.1006/anbo.2000.1270
Tavallali, V., Rahemi, M., Eshghi, S., Kholdebarin, B., Ramezanian, A. (2010). Zinc alleviates salt stress and increases antioxidant enzyme activity in the leaves of pistachio (Pistacia vera L. Badami) seedlings. Turkish Journal of Agriculture and Forestry, 34(4), 349-359.

Toor, R. K., Savage, G. P. (2005). Antioxidant activity in different fractions of tomatoes. Food Research International, 38(5), 487-494. doi:10.1016/j.foodres.2004.10.016

Tossi, V., Lamattina, L., Cassia, R. (2009). An increase in the concentration of abscisic acid is critical for nitric oxide-mediated plant adaptive responses to UV-B irradiation. New phytologist, 181(4), 871-879. doi:10.1111/j.1469-8137.2008.02722.x

Ulm, R., Nagy, F. (2005). Signalling and gene regulation in response to ultraviolet light. Current Opinion in Plant Biology, 8(5), 477-482. doi:10.1016/j.pbi.2005.07.004

Wagner, G. J. (1979). Content and vacuole/extravacuole distribution of neutral sugars, free amino acids, and anthocyanin in protoplasts. Plant Physiology, 64(1), 88-93. doi:10.1104/pp.64.1.88

Wei, Z. F., Luo, M., Zhao, C. J., Li, C. Y., Gu, C. B., Wang, W., Zu, Y. G., Efferth, T., Fu, Y. J. (2013). UV-induced changes of active components and antioxidant activity in Postharvest Pigeon Pea [Cajanus cajan (L.) Millsp.] Leaves. Journal of Agriculture and Food Chemistry, 61(6), 1165-117. doi:10.1021/jf304973f

Weisany, W., Sohrabi, Y., Heidari, G., Siosemardeh, A., Ghassemi-Golezani, K. (2012). Changes in antioxidant enzymes activity and plant performance by salinity stress and zinc application in soybean (Glycine max L.). Plant Omics, 5(2), 60-67.

Winterbourn, C. C., McGrath, B. M., Carrell, R. W. (1976). Reactions involving superoxide and normal and unstable haemoglobins. The Biochemical Journal, 3(155), 493-50. doi:10.1042/bj1550493

Zlatev, S. Z., Lidon, F. J. C., Kaimakanova1, M. (2012). Plant physiological responses to UV-B radiation. Emirates Journal of Food Agriculture, 24(6), 481-501. doi:10.9755/ejfa.v24i6.481501

Zu, Y., Li, Y., Chen, J., Chen, H. (2004). Intraspecific responses in grain quality of 10 wheat cultivars to enhanced UV-B radiation under field conditions. Journal of Photochemistry and Photobiology,74(2-3), 95-100. doi:10.1016/j.jphotobiol.2004.01.006 